\title{
OP-61腎細胞癌に対する骨蹃非破壊的同種末梢 血幹細胞移植の経験
}

\begin{abstract}
札幌医科大学 医学部 泌尿器科"
札幌医科大学 医学部 第四内科2)

舛森 直哉", 松永 卓也 ${ }^{2}$, 高橋 敦", 伊藤 直樹"

坂牧 純夫 ${ }^{21}$, 新津 洋司郎"2, 塚本 泰司"

【目的】転移性腎細胞癌に対する $\alpha$-IFN や IL-2 の奏功率はいず れも $15 \%$ 程度であり満足な成績は得られていない。一方、骨㕼非 破壊的同種末梢血幹細胞移植 (ミニ移植) は、転移性腎細胞癌に 対する新たな免疫療法の strategy としてその有効性が注目され ている。今回我々は、転移性腎細胞癌患者に対してミニ移植を施 行したので、その経過を報告する。【方法]症例は 41 才男性。左腎 細胞癌 (淡明細胞癌、G2、pT2pNOM0)に対する根治的腎摘除術 1 年後に肺転移が出現した。 $\alpha$-IFN および IL-2による治療はいず れも無効であり、患者およびドナーへのインフォームドコンセントの 上、骨鹃非破壊的同種末梢血幹細胞移植を施行した。HL 6 6 6 マッチの兄より得た CD34 陽性細胞 $14 \times 10^{5} / \mathrm{kg}$ を、fludarabine $25 \mathrm{mg} / \mathrm{m}^{2} 5$ 日間および cyclophosphamide $30 \mathrm{mg} / \mathrm{kg} 2$ 日間に 上る骨剈非破壊的化学療法後に患者に輸注した。成績]移植後 28 日目のキメリズム解析で完全キメラが得られなかったため、免 疫抑制凪中止後に $1 \times 10^{7} / \mathrm{kg}$ のドナーリンバ球輸注 (DLI)を追加 した。移植から DLI までの効果は PD、DLI から移植後 72 日まで の効果は NCと判定された。なお、移植後 72 日までの経過中に明 らかな graft-versus-host disease は認めなかった。

腎細胞癌 骨蹃非破塤的同種末梢血幹細胞移植
\end{abstract}

\section{OP-62 進行性腎細胞癌に対するミ二移植}

\section{OP-63}

骨噵非破塤的同種造血幹細胞移植( 三二 移植)を行った転移性腎細胞癌の 2 例

\begin{abstract}
日赤和歌山医療センター 第 1 泌尿器科" 日赤和歌山医 療センター 第 2 内科2) 奈良県立医科大学 ${ }^{3)}$

日裏 勝", 高橋 彰", 直川匡晴2, 米谷 昇 ${ }^{2}$, 西山隆一" 北原光輝", 金岡 俊雄 ${ }^{11}$, 林 正", 杉山建生 ${ }^{2)}$, 吉田 修 【目的】転移性堅綀胞癌に対してミ二移植を施行した 2 例を報告す る。対象と方法]症例 1 は 68 歳、男性。左腎腫瘍術後、IFN- $\alpha$ 抵抗 性の右肺転移に肺部分切除を施行。その後、出現した左肺多発転移 に対して、IL-2を投与したが増大傾向を認めたため、H13 年 7 月 5 日 ミ二移植を施行した。症例 2 は 73 歳、男性。左腎腫演、骨転移。原発 巣に塞栓術、転移巣に放射線照射の後 IFN- $\alpha$ を投与したが、肺転移 が出現。IL-2に変更したが、効果がみられないため、H13 年 8 月 15 日ミ二移植を施行したPSは症例 1,2とも0-1。組織型は症例 1 が chromophobe cell、症例 2 が clear cell であった。移植前処置として fludarabine $25 \mathrm{mg} / \mathrm{m}^{2} \times 5$ 日, TBI $2 \mathrm{~Gy}$ を行った後、症例 1 は HLA 一致の実弟ドナ一からの末梢血幹細胞之骨鹖採取液を移植し、症例 2 はHLA 一致の実兄ドナーからの骨暍採取液を移植したGVVHD 予防はCyA と miniMTXを用いた。成績]症例 1 は Day+56で完 全キメラとなった。day+50 頃より皮凬に急性の GVHD が出現 (grade 2)、その後慢性 GVHDに移行した。左肺転移巣は、移植後一時 38.5 $\%$ 増大の後に day +70 頃より縮小し始め、day+104で移植前の約 $1 /$ 3 に縮小した $(\mathrm{PR})$ 。症例 2 は day+27で混合キメラ.CyA 減量でも 変化ないため DLI(ドナーリンパ球輸注)を 3 回行った。

転移性腎細胞癌 ミニ移植
\end{abstract}

\section{OP-64転移性腎細胞癌に対するミニトランスプラ ントの経験}

\section{金沢大学 大学院 医学系研究科 がん医科学 集学的 治療学" 金沢大学 大学院 医学系研究科 がん医科学 細胞移植学 ${ }^{2)}$ 有松中央病院 泌尿器科 ${ }^{3)}$}

越田 潔", 石浦 嘉之", 小松和人", 江川 雅之"

溝上 敦", 並水 幹夫", 高見 昭良 ${ }^{2}$, 中尾 眞二"2)

宮崎 公臣 ${ }^{3}$

【目的】IFN/IL-2 抵抗性の転移性進行性腎細胞癌 3 例に对し てミニトランスプラントを施行したのでその臨床経過について報 告する。対象]64歳、52 歳の男性および 58 歳の女性であり、先 の 2 例は腎摘後、肺、骨あるいは肺、骨、副腎、リンパ節に転移を 来たし、残りの 1 例は局所浸潤性の原発巣ならびに胸膜、骨、副 腎、リンパ節に転移巣を持った進行症例であった。【方法】CPA $60 \mathrm{mg} / \mathrm{kg} \times 2 \mathrm{~d}$. FDR $25 \mathrm{mg} / \mathrm{m} 2 \times 5 \mathrm{~d}$ にて前処置を行い HLA の一致した同胞より末梢血幹細胞移植を行った。成績】T 細胞 の $100 \%$ ドナー化は移植後それぞれ 94, 52, 40 日で達成され、 急性 GVHD は症例 2.3で36.53 日で観察された。また慢性 GVHD は症例 1.2で 75,183 日で認められた。治療効果として は症例 1 で一時的な腫㙏縮小を部分的に認めるも、症例 1,2 に おいて移植後 15 力月、7 カ月経過した時点で NC であり、症例 3 は69 日で癌死した。結論】T細胞のドナー化は全例で達成 されたが明らかな抗腫㻛効果は認められず、さらに患者のQOL は慢性 GVHD のため必ずしも満足のいくものではない。 腎癌 ミニトランスプラント 免疫治療 